\title{
Feather degradation potential of Stenotrophomonas maltophilia KB13 and feather protein hydrolysate (FPH) mediated reduction of hexavalent chromium
}

\author{
Khushboo Bhange $^{1} \cdot$ Venkatesh Chaturvedi $^{2} \cdot$ Renu Bhatt $^{1}$
}

Received: 16 May 2015/Accepted: 10 September 2015/Published online: 2 February 2016

(c) The Author(s) 2016. This article is published with open access at Springerlink.com

\begin{abstract}
An efficient keratinolytic strain of Stenorophomonas maltophilia KB13 was isolated from feather disposal site of Bilaspur, Chhattisgarh, India. The strain could metabolize $10 \mathrm{~g} / \mathrm{l}$ chicken feathers as sole source of carbon and nitrogen. Soluble protein, amino acid, and cysteine content were found to be maximum $(690.6 \pm 8.7$, $688.9 \pm 9.12$ and $21 \pm 0.36 \mu \mathrm{g} / \mathrm{ml}$, respectively) at late logarithmic phase of growth. Protease and keratinase activity reached its maximum level $(103.26 \pm 7.09$ and $178.5 \pm 9.10 \mathrm{U} / \mathrm{ml})$ at the 4 th day of incubation. The feather protein hydrolysate (FPH) obtained after degradation of chicken feathers was utilized to reduce hexavalent chromium. About $78.4 \pm 2.4$ and $63.6 \pm 2.2 \%$ reduction of 50 and $100 \mathrm{mg} / \mathrm{l} \mathrm{Cr}(\mathrm{VI})$, respectively, was observed after $60 \mathrm{~min}$ of incubation with FPH. Further, there was no effect of autoclaved FPH on $\mathrm{Cr}(\mathrm{VI})$ reduction indicating that any bacterial enzyme was not involved in reduction process. $\mathrm{Cr}(\mathrm{VI})$ reduction was significantly inhibited by $10 \mathrm{~mm} \mathrm{Hg}^{2+}$ ions indicating the role of sulfur-containing amino acids in reduction process. FTIR analysis confirmed that chromium reduction occurred due to oxidation of amino acids cysteine and cystine. This study shows that FPH arising after feather degradation can be employed as a potential candidate for the reduction of hexavalant chromium.
\end{abstract}

Renu Bhatt

dr.renubhatt@yahoo.com

1 Department of Biotechnology, Guru Ghasidas Vishwavidyalaya (A Central University), Bilaspur, Chhattisgarh 495009, India

2 School of Biotechnology, Banaras Hindu University, Varanasi, U.P., India
Keywords Stenotrophomonas maltophilia KB13 . Feather degradation - Feather protein hydrolysate . $\mathrm{Cr}(\mathrm{VI})$ reduction

\section{Introduction}

Feathers are considered as a potent waste generated in large amount by various poultry industries around the world. Feathers consist largely of insoluble protein keratin, which contains high degree of cross linking by disulfide bonds, hydrogen bonding, and hydrophobic interactions (Jeong et al. 2010). These interactions present in keratin make it highly recalcitrant in nature and its accumulation creates serious environmental concern. Various physical and chemical treatments are employed in efficient degradation of feathers, but these processes are mostly energy consuming and the resulting feather lysates are deficient in heat-sensitive amino acids such as methionine, lysine, and tryptophan (Tiwary and Gupta 2010). The hydrolysis of feathers by keratinolytic microorganisms represents alternative method to reduce energy loss and environmental pollution load (Fang et al. 2013).

Various bacteria, actinomycetes, and fungi are known to produce keratinolytic enzymes to degrade keratin and to metabolize it as carbon and nitrogen source (Tiwary and Gupta 2010). Most researches on microbial keratinases have been reported on Gram-positive bacteria, such as Streptomyces spp. (Tatineni et al. 2008; Syed et al. 2009) and Bacillus spp. (Lateef et al. 2010; Shrinivas and Naik 2011). However, some Gram-negative bacteria, such as Chryseobacterium sp. (Riffel et al. 2007), Aeromonas hydrophila K12, Stenotrophomonas maltophia (Yamamura et al. 2002; Jeong et al. 2010; Fang et al. 2013), Serratia marcescens P3 (Bach et al. 2012), and Pseudomonas 
stutzeri (Chaturvedi et al. 2014) have also been described as efficient keratin-degrading strains. All these microorganisms metabolize feathers as a source of carbon and nitrogen and release high amounts of free amino acids/ short peptides in the culture medium (Yamamura et al. 2002). These are collectively termed as feather protein hydrolysates (FPH) and can be utilized as slow-release nitrogen fertilizers (Lasekan et al. 2013), antioxidants (Fontoura et al. 2005) or for production of glutathione (Taskin 2013), Exopolysaccharides (Taskin et al. 2012), Biohydrogen (Bálint et al. 2005). The presence of high amounts of free amino acids also makes it a good reducing agent. However, this property has not been much explored.

Hexavalent chromium is employed in industries such as leather tanning, metallurgy, electroplating (Ataabadi et al. 2015), petroleum refining, textile manufacturing, etc. (Allegretti et al. 2006) and, therefore, huge amounts of chromium are being discharged in the environment. Chromium exists in two oxidation states, $\mathrm{Cr}(\mathrm{VI})$ and $\mathrm{Cr}(\mathrm{III})$, where $\mathrm{Cr}(\mathrm{VI})$ is highly toxic to plants, animals, and humans. $\mathrm{Cr}(\mathrm{VI})$ has high solubility and thus is mobile in soils and ground water and whereby it gains entry into plants and animals and elicits acute toxicity. In contrast, $\mathrm{Cr}(\mathrm{III})$ precipitates as $\mathrm{Cr}(\mathrm{OH})_{3}$ under alkaline or weak acidic conditions; thus it is less mobile and toxic (Chen et al. 2007). Therefore, reduction of $\mathrm{Cr}(\mathrm{VI})$ to $\mathrm{Cr}$ (III) is considered as an efficient method for chromium removal and to reduce its toxicity in environment (Megharaj et al. 2003). Studies have shown that chromium can be reduced by various chemical and biological methods. Adsorption (Santhana et al. 2014), Chemicals such as ferrous [Fe(II)] compounds (Ren et al. 2013), Anion exchange resins (Deng et al. 2010), Electrolysis (Welch et al. 2005), etc. can efficiently reduce chromium compounds (Wang et al. 2012). However, these compounds are chemically synthesized, costly, and also not safe. Biological method involves use of microbes and their enzymes, which reduce chromium VI to chromium III (Thatoi et al. 2014). Several microorganisms such as Exiguobacterium sp. (Alam and Malik 2008), Ochrobacterium intermedium (Sultan and Hasnain 2007), Stenotrophomonas maltophilia, Pantoea sp., and Aeromonas sp. (Alam and Ahmad 2012) have been shown to reduce hexavalent chromium.

In the present investigation, a strain of S. maltophia KB13 was utilized to metabolize chicken feathers as sole source of carbon and nitrogen. FPH arising after degradation of chicken feathers by this isolate was used to reduce hexavalent chromium. This is the first report showing potential use of FPH as an inexpensive source for chromium removal.

\section{Materials and methods}

\section{Materials}

Feathers were procured from regional poultry farm of Bilaspur, Chhattisgarh, India, washed extensively with tap water, dried at $60{ }^{\circ} \mathrm{C}$ for 2 days, and then kept at room temperature until used. All chemicals and other reagents were of pure grade and purchased from Sigma chemicals, India.

\section{Preparation of media and culture condition}

Bacterial strain was grown on feather meal broth (FMB) containing (g/l) $\mathrm{K}_{2} \mathrm{HPO}_{4} \quad 0.4, \mathrm{KH}_{2} \mathrm{PO}_{4} \quad 0.3, \mathrm{NaCl} 0.5$, chicken feathers 10 (Tatineni et al. 2008). pH was adjusted to 7.5 before sterilization. For subculturing and storing, Feather Meal Agar (FMA) was employed, which contained (g/l) $\mathrm{K}_{2} \mathrm{HPO}_{4} 0.3, \mathrm{KH}_{2} \mathrm{PO}_{4} 0.4, \mathrm{NaCl} 0.5, \mathrm{MgCl}_{2} \cdot 6 \mathrm{H}_{2} \mathrm{O}$ 0.1 , and feather 10 and agar 15. Peptone water was employed for inoculums preparation containing (g/l) peptone 10 , and $\mathrm{NaCl} 5$ ( $\mathrm{pH} 7.4$ ). All cultivation media were autoclaved at $121{ }^{\circ} \mathrm{C}, 105 \mathrm{kPa}$ for $15 \mathrm{~min}$.

\section{Isolation of feather degrading bacterial strain and phylogenetic analysis}

Feather-degrading bacteria were isolated employing enrichment technique. Soil samples were collected from feather disposal site of Bilaspur, Chhattisgarh. One gram (1 g) of soil was suspended in $0.9 \%$ saline solution and vortexed for 2-3 min intermittently. The supernatant was inoculated in $100 \mathrm{ml}$ Erlenmeyer flask containing $50 \mathrm{ml}$ FMB supplemented with $10 \mathrm{~g} / \mathrm{l}$ chicken feathers as sole source of carbon and nitrogen. The inoculated flask was kept for incubation at $32{ }^{\circ} \mathrm{C}$ and $150 \mathrm{rpm}$ in rotator shaker (Remi, CIS-24 BL) for 3 days. Five milliliter $(5 \mathrm{ml})$ culture suspension was transferred subsequently to $50 \mathrm{ml}$ of fresh FMB and incubated for 3 days at $32{ }^{\circ} \mathrm{C}$. The suspension was serially diluted; $100 \mu$ l of suspension was spread on FMA and was incubated at $32{ }^{\circ} \mathrm{C}$ for $48 \mathrm{~h}$. The morphologically distinct colony of bacterial cells was individually inoculated on fresh FMB and incubated at same condition mentioned above for 3 days. Feather degradation potential of each stain was assessed by estimating soluble protein content of supernatant (Bradford 1976) and by measuring residual feather content. The isolate exhibiting highest soluble protein content and least amount of residual feather was considered as potential feather degrading strain and selected for further study.

The selected strain was characterized by physiological and biochemical parameters as described in Bergey's 
Manual of Determinative Bacteriology (9th edition) (Holt et al. 1994). Identification of this strain was performed by partial gene sequencing of $16 \mathrm{~S}$ rDNA commercially (Chromous Biotech Pvt. Ltd) by primers 27 F (AGA GTT TGA TCM TGG CTC AG) and 518 R (GTA TTA CCG CGG CTG CTG G). The sequence was submitted to genbank NCBI for retrieval of accession number.

\section{Time course study of feather degradation}

A single colony of strain KB13 was inoculated in $250 \mathrm{ml}$ Erlenmeyer flask containing $50 \mathrm{ml}$ of peptone water and incubated at $35^{\circ} \mathrm{C}$ and $125 \mathrm{rpm}$ in an orbital shaker. After overnight growth, the culture was centrifuged at 10,000 rpm for 10 min (Remi C-24 BL). The cell pellet was washed twice and suspended in $5 \mathrm{ml}$ FMB (without feathers). Five percent $(\mathrm{v} / \mathrm{v})$ inoculums $\left(3 \times 10^{8}\right.$ $\mathrm{CFU} \mathrm{ml}{ }^{-1}$ ) were added to $100 \mathrm{ml}$ of FMB (containing $10 \mathrm{~g} / \mathrm{l}$ chicken feather) and incubated at the same conditions. Samples $(2 \mathrm{ml})$ were retrieved from each of triplicate cultures every $24 \mathrm{~h}$ to evaluate growth, soluble protein production, and enzyme activity. Triplicate assays were performed for each parameter.

\section{Estimation of growth}

Growth was estimated using TTC reduction method and absorption was measured at $480 \mathrm{~nm}$ (De Logu et al. 2001). Briefly, to $1 \mathrm{ml}$ of culture suspension $10 \mu \mathrm{l}$ of $0.02 \%$ TTC solution was added and was incubated at $32{ }^{\circ} \mathrm{C}$ for $30 \mathrm{~min}$. The cell suspension was then centrifuged at $10,000 \mathrm{rpm}$ for 10 min. Supernatant was discarded and $1 \mathrm{ml}$ of $95 \%$ ethanol was added to the cell pellet and kept for shaking $(150 \mathrm{rpm})$ at $32{ }^{\circ} \mathrm{C}$ and subsequently centrifuged at $10,000 \mathrm{rpm}$ for $10 \mathrm{~min}$. The absorbance of supernatant was recorded at $480 \mathrm{~nm}$. Protein concentration was determined using Bradford method (1976) and bovine serum albumin (BSA) as standard. The absorbance was determined spectrophotometrically at $590 \mathrm{~nm}$ using UV-Vis spectrophotometer (UV-1800, Shimadzu). Total amino acid content was measured by manual ninhydrin method by taking leucine as standard (Cheng et al. 2010).

\section{Enzyme assay}

Keratinase assay was performed according to the method of Anbu et al. (2007) with minor modifications. Twenty $\mathrm{mg}$ $(20 \mathrm{mg}$ ) of chopped feathers was suspended in $3.8 \mathrm{ml}$ of $100 \mathrm{mM}$ Tris-HCl buffer ( $\mathrm{pH}$ 8.0) followed by addition of $200 \mu \mathrm{l}$ of culture supernatant to it. This preparation was incubated at $50{ }^{\circ} \mathrm{C}$ and $120 \mathrm{rpm}$ for $1 \mathrm{~h}$ and the reaction was stopped by cooling the tubes in ice chilled water. After centrifugation at $5000 \mathrm{rpm}$ for $5 \mathrm{~min}$, the absorbance of supernatant was measured at $280 \mathrm{~nm}$. Control samples were prepared in a similar manner except that the enzyme was replaced by same volume of $100 \mathrm{mM}$ Tris- $\mathrm{HCl}$ buffer (pH 8.0). One unit of enzyme activity was considered as the amount of enzyme required to release $1 \mu \mathrm{mol} / \mathrm{min}$ of tyrosine. Similarly, protease activity was determined with the above mentioned conditions using casein as the substrate.

\section{Estimation of cysteine content}

Cysteine content was estimated by Ellman's reagent (Ellman 1959). To $250 \mu \mathrm{l}$ of standard cysteine solution, $2.5 \mathrm{ml}$ of phosphate buffer $(100 \mathrm{mM}, \mathrm{pH} 7.2)$ and $50 \mu \mathrm{l}$ of Ellman's reagent were added. The solution was vortexed and incubated at room temperature of $15 \mathrm{~min}$. The absorbance was recorded at $412 \mathrm{~nm}$. For estimation of cysteine in chicken feather hydrolysate, $250 \mu \mathrm{l}$ of chicken feather hydrolysate obtained from ( $48 \mathrm{~h}$ old culture) was taken instead of standard cysteine solution, and the rest of steps were same as mentioned.

\section{Reduction of hexavalent chromium}

To $1 \mathrm{ml}$ of chicken feather hydrolysate, $50,100 \mathrm{mg} / \mathrm{l}$ chromium(VI) was maintained by adding different volumes of potassium dichromate stock solution $(1 \mathrm{mg} / \mathrm{ml})$. The solution was incubated for $1 \mathrm{~h}$ and then residual chromium(VI) was estimated by carbazide reagent. In control, $50,100 \mathrm{mg} / \mathrm{l}$ chromium(VI) was prepared in double-distilled water. To study the reduction of hexavalent chromium by cysteine and methionine different concentration of these amino acids (10-50 ppm) was prepared in doubledistilled water and employed for chromium reduction assay. Similarly, the FPH was concentrated twice using lyophilizer (Mac HC 333, India) and was used to study chromium reduction. To study the role bacteria in reduction process, strain KB 13 was grown for $48 \mathrm{~h}$ in FMB (without chicken feathers) supplemented with glucose ( $1 \mathrm{~g} /$ 1) and $\mathrm{NH}_{4} \mathrm{Cl}(1 \mathrm{~g} / \mathrm{l})$, respectively. After $48 \mathrm{~h}$ of growth the culture was centrifuged at $10,000 \mathrm{rpm}$ for $10 \mathrm{~min}$. The culture supernatant was filtered through Whatman filter paper No.1 and supernatant was used for reduction assay as mentioned above.

\section{Estimation of hexavalent chromium}

Hexavalent chromium was estimated as per the method of Eaton et al. (2005). To $1 \mathrm{ml}$ of potassium dichromate solution, $200 \mu \mathrm{l}$ of $1 \mathrm{M}$ sulfuric acid and $500 \mu \mathrm{l}$ of carbazide reagent were added and incubated for $30 \mathrm{~min}$. The absorbance of solution was recorded at $540 \mathrm{~nm}$. In control $1 \mathrm{ml}$ double-distilled water was used. To prepare carbazide 
reagent, to $0.05 \mathrm{~g} 1,5$ diphenyl carbazide, $2 \mathrm{ml}$ glacial acetic acid was added. The final volume was maintained $25 \mathrm{ml}$ by adding double-distilled water. The carbazide reagent was stored at $4{ }^{\circ} \mathrm{C}$ until use.

\section{Determination of minimum inhibitory concentration (MIC)}

MIC was evaluated by growing the strain in nutrient broth supplemented with different concentrations of hexavalent chromium (10-50 ppm) at $32{ }^{\circ} \mathrm{C}$ for $48 \mathrm{~h}$. The minimum concentration of chromium at which no growth was observed was considered as the MIC of strain.

\section{FTIR analysis}

For FTIR analysis, potassium dichromate was treated with FPH. Final concentration was maintained at $50 \mathrm{mg} / \mathrm{l}$. After $1 \mathrm{~h}$ of treatment the sample was dried in vacuum drier. Feather protein hydrolysate was taken as control. The samples were mixed with spectroscopically pure $\mathrm{KBr}$ in ration of 5:95 (sample: KBr). Pellets were fixed in sample holder and analysis was carried out using Shimadzu 8400 FTIR spectrometer.

\section{Results and discussion}

Eight potential keratinolytic strains were isolated from soil samples collected from feather disposal site on the basis of enrichment technique in minimal medium containing chicken feathers $(10 \mathrm{~g} / \mathrm{l})$ as sole carbon and nitrogen source. Strain KB13 was found to be the potent keratinolytic strain and only $13.8 \%$ residual feather remained in the medium after 4 days of incubation. The strain KB13 was a Gram-negative, rod-shaped motile bacterium. 16S rDNA analysis revealed its $97 \%$ similarity with S. maltophilia strain SSASC23 on BLAST search at NCBI. The strain was identified as $S$. maltophilia strain KB13 (Accession No. KC818432.1). This is in accordance with previous reports, indicating that $S$. maltophilia can metabolize chicken feathers Yamamura et al. (2002), Jeong et al. (2010) and Fang et al. (2013).

The time course study of feather degradation was performed in feather meal broth containing $10 \mathrm{~g} / \mathrm{l}$ feather as sole source of carbon and nitrogen. The level of soluble protein and amino acid content showed a gradual increase and reached its maximum $(690.6 \pm 8.7$ and $688.9 \pm 9.12 \mu \mathrm{g} / \mathrm{ml}$ ) at late logarithmic phase of growth (Fig. 1a). Maximum cysteine content in FPH was $21 \pm 0.36 \mu \mathrm{g} / \mathrm{ml}$ during this period (Fig. 1b). Feather degradation process usually starts from feather barbs and progresses with the degradation of feather rachis
(Chaturvedi et al. 2014). In the present study feather degradation by the strain of $S$. maltophilia KB13 exhibited a similar trend. Keratinase and protease activity reached the maximum level $(103.26 \pm 7.09$ and $178.5 \pm 9.10 \mathrm{U} /$ $\mathrm{ml}$ ) on the 4th day of cultivation (Fig. 1c). These results were consistent with those of previous reports (Jeong et al. 2010; Chaturvedi et al. 2014).

Reports have shown that free amino acids such as cysteine, methionine, and cystine can reduce hexavalent chromium to trivalent chromium. Kwong and Pennington (1983) demonstrated that L-cysteine can reduce hexavalent chromium to trivalent chromium according to reaction.

$\mathrm{HCrO}_{4}^{-}+2 \mathrm{~L}-\mathrm{Cys} \mathrm{SH} \rightarrow$ L-Cystine $+\mathrm{HCrO}_{3}^{-}$

In another study by Adari et al. (2008), it was observed that L-cystine can also reduce chromium(VI) to Chromium(III) according to the reaction.

3 cystine $+10 \mathrm{Cr}(\mathrm{VI}) \rightarrow 6$ cysteic acid $+10 \mathrm{Cr}(\mathrm{III})$

Chicken feather hydrolysate contained high amounts of cysteine, cystine and, therefore, can be utilized for reduction of hexavalent chromium. The FPH produced at late logarithmic phase of growth after degradation of chicken feathers was employed for reduction of hexavalent chromium. In the present study, significant reduction of chromium(VI) was observed after incubation of chicken feather hydrolysate with 50 and $100 \mathrm{mg} / \mathrm{l}$ chromium(VI) for $1 \mathrm{~h}$ (Fig. 2a). It was also observed that the rate of reduction of $50 \mathrm{mg} / \mathrm{l}$ chromium(VI) was higher than $100 \mathrm{mg} / \mathrm{l}$ concentration. This might be due to the fact that the concentration of amino acids was limiting at higher concentration of chromium(VI). To confirm this hypothesis, FPH was concentrated twice and was employed for chromium reduction. It was observed that in the presence of $\mathrm{FPH}$, reduction of hexavalent chromium was $58 \pm 5.2 \%$ and in the presence of concentrated FPH reduction was $87 \pm 4.2 \%$. This result clearly shows that amino acids play a role in reduction of hexavalent chromium. As the amount of amino acids increases due to concentration of $\mathrm{FPH}$, the rate of chromium reduction has also substantially increased. Tsopmo et al. (2014) have also previously described the reduction of hexavalent chromium by digested oat bran protein and role of cysteine in reduction process. Since, reduction of hexavalent chromium has also been reported by $S$. maltophilia (Alam and Ahmad 2012). Therefore, strain KB13 was grown for $48 \mathrm{~h}$ in minimal medium, the culture supernatant was used to reduce hexavalent chromium. The result showed that no reduction of chromium was observed. Further Minimum Inhibitory Concentration (MIC) of this isolate towards hexavalent chromium was calculated. MIC was found to be $40 \mathrm{ppm}$, which indicated that this strain was sensitive towards chromium. The characters of 
Fig. 1 Time course study of growth and feather degradation by $S$. maltophilia $\mathrm{KB} 13$ on FMB supplemented with $10 \mathrm{~g} / 1$ chicken feathers, incubated at $120 \mathrm{rpm}, 30^{\circ} \mathrm{C}$. Time course study of a growth and soluble protein production, $\mathbf{b}$ amino acid and cysteine production, c protease and keratinase activity. The result is represented as mean \pm standard error of three independent variables
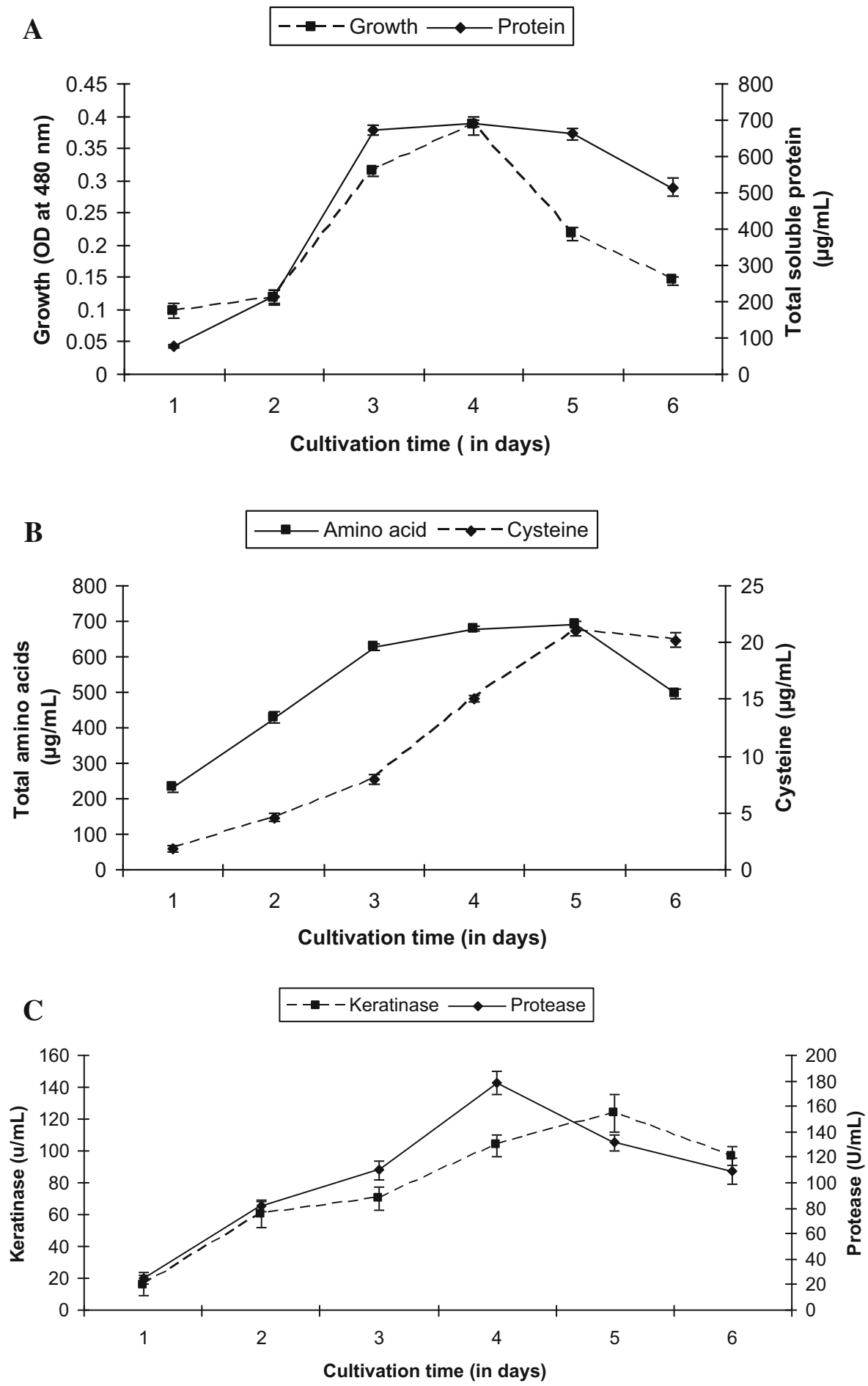

microorganisms are closely related to habitats to which they belong. S. maltophilia ZA-6 was recovered from soil irrigated with tannery effluents containing high amounts of chromium (Alam and Ahmad 2012) which enabled the bacterium to resist and reduce hexavalent chromium. As strain KB13 was isolated from a feather disposal site and not from the chromium-rich soil, it was able to metabolize chicken feathers but was sensitive to chromium. To further rule out the role of any bacterial enzyme in reduction process, the hydrolysate was autoclaved at $121{ }^{\circ} \mathrm{C}$ at $15 \mathrm{~atm}$ pressure for $20 \mathrm{~min}$. It was cooled at RT and chromium oxidation assay was performed. It was observed that at a concentration of $50 \mathrm{mg} / \mathrm{l}$ chromium(VI), the rate of reduction was slightly higher in autoclaved feather hydrolysate as compared to un-autoclaved samples (Fig. 2b). 
Fig. 2 Feather protein hydrolysate mediated reduction of hexavalent chromium (a) reduction of 50 and $100 \mathrm{mg} / \mathrm{l}$ chromium(VI) after 30 and $60 \mathrm{~min}$. b Reduction of $50 \mathrm{mg} / \mathrm{l}$ chromium(VI) through autoclaved and unautoclaved feather hydrolysate (c) reduction of 50 and $100 \mathrm{mg} / \mathrm{l}$ chromium(VI) in the presence of $5 \mathrm{mM}$ and $10 \mathrm{mM} \mathrm{Hg}^{2+}$ concentration
A
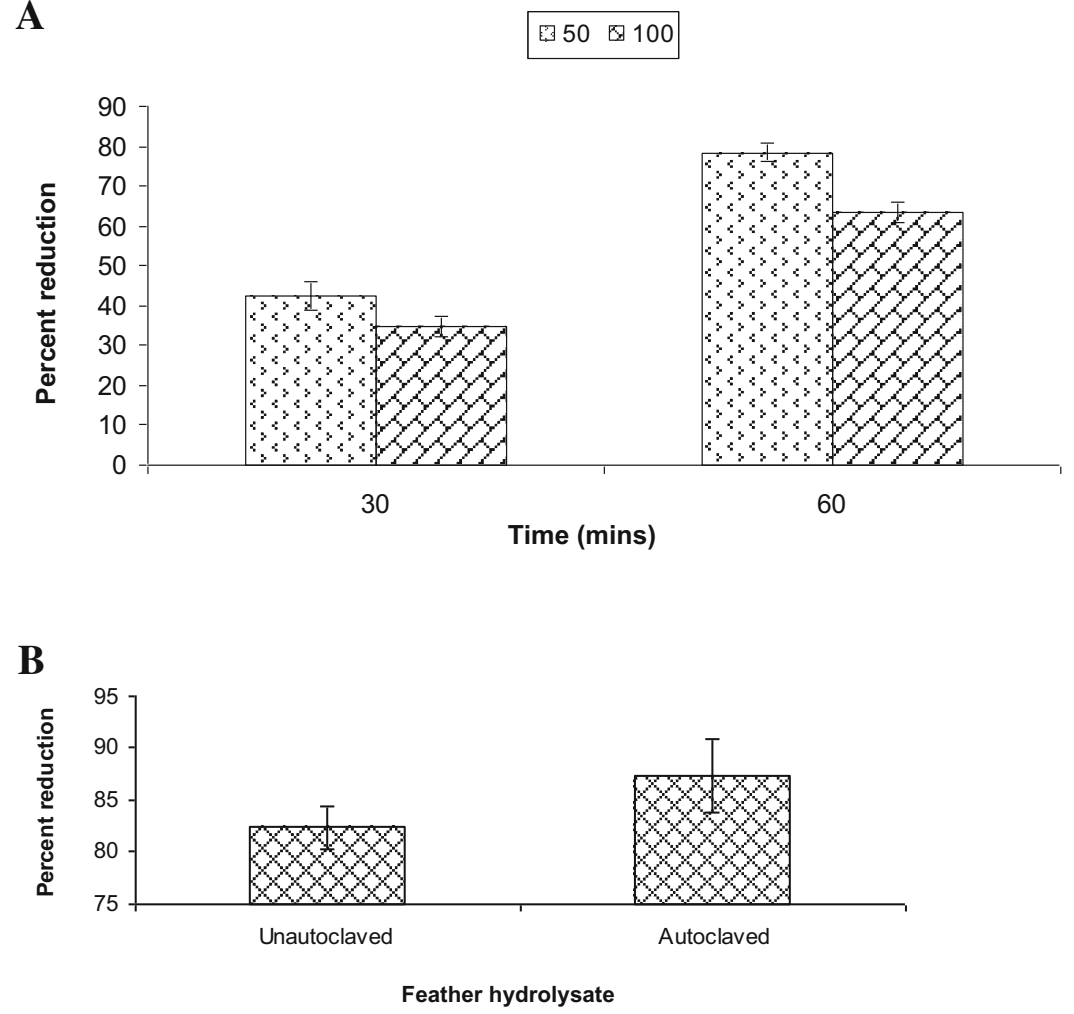

C
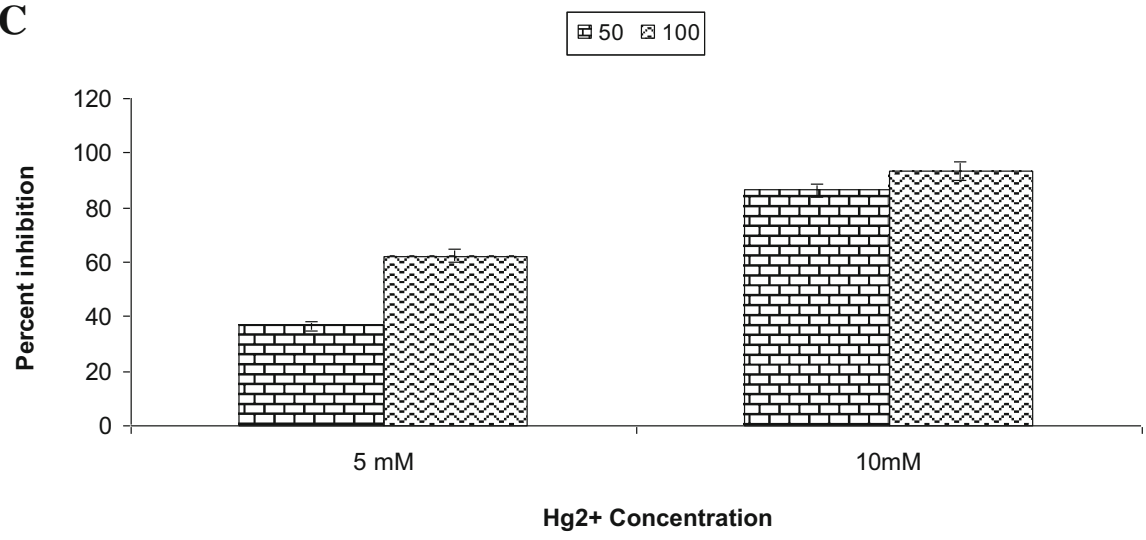

Since concentration of amino acids vary considerably in $\mathrm{FPH}$, reduction of $50 \mathrm{mg} / \mathrm{l}$ hexavalent chromium was performed with varying concentrations of cysteine and methionine, respectively (Fig. 3). A dose-dependent relationship was observed with chromium reduction and concentration of amino acid: with an increase in concentration of amino acid an increase in chromium reduction was observed. However, the reduction was low as compared to that observed in FPH. Since FPH contains a mixture of amino acids, reduction takes place by combined action of these amino acids and higher reduction was observed. Quievryn et al. (2001) have reported that glutathione and cysteine are main reducers of hexavalent chromium in humans exposed to high concentration of chromium. In this study, hexavalent chromium was reduced to chromium(III). We proposed that a similar mechanism is involved in reduction of hexavalent chromium by FPH. Since concentration of cysteine in FPH is very high $(21 \pm 0.36 \mu \mathrm{g} /$ $\mathrm{ml}$ ), high amount of hexavalent chromium (50 and $100 \mathrm{mg}$ / 1) was reduced.

To further confirm this hypothesis, chromium reduction was studied in the presence of $\mathrm{Hg}^{2+}$ ions, since $\mathrm{Hg}^{2+}$ ions are considered as potent inhibitor of sulfur-containing amino acids such as cysteine, cystine, and methionine, respectively. $\mathrm{Hg}^{2+}$ irreversibly binds to these amino acids and inhibits their activity (Focardi et al. 2012). To further 
confirm the role of these amino acids in reduction of hexavalent chromium, 5 and $10 \mathrm{mM}$ concentration of $\mathrm{Hg}^{2+}$ ions were added to $\mathrm{FPH}$ and chromium reduction was estimated (Fig. 2c). It was observed that in the presence of $5 \mathrm{~mm} \mathrm{Hg}^{2+}$ ions, $36.5 \pm 1.4$ and $62.3 \pm 2.3 \%$ inhibition in chromium reduction at 50 and $100 \mathrm{mg} / \mathrm{l}$ chromium(VI) was observed. Similarly, in the

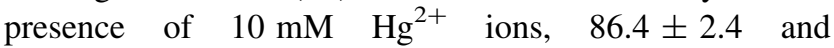
$93.2 \pm 3.5 \%$ inhibition in chromium reduction at 50 and $100 \mathrm{mg} / 1$ chromium(VI) was observed. This result clearly demonstrates the role of sulfur-containing amino acids in reduction of hexavalent chromium.

To further confirm the role of amino acid cysteine in reduction of hexavalent chromium, FTIR analysis of

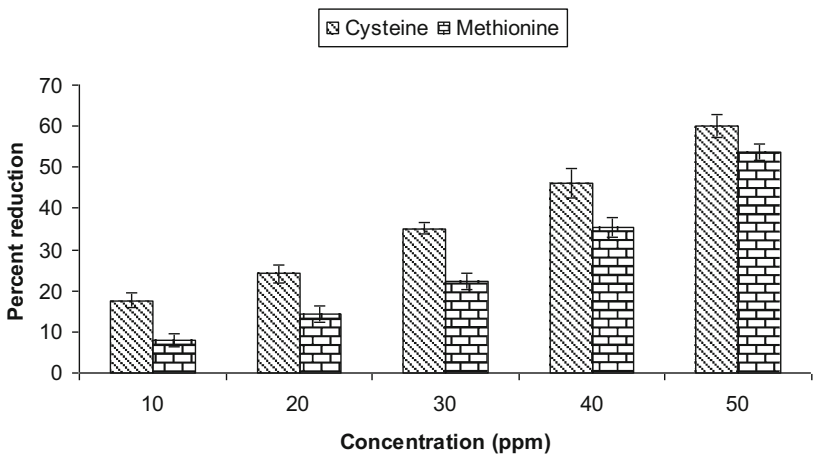

Fig. 3 Reduction of $50 \mathrm{mg} / \mathrm{l}$ hexavalent chromium in the presence of varying concentrations of cysteine and methionine, respectively, after $1 \mathrm{~h}$ of incubation feather protein lysate and feather protein lysate containing $50 \mathrm{mg} / \mathrm{l}$ potassium dichromate was performed. The FTIR spectrum is depicted in Fig. 4. The FTIR spectrum of feather protein lysate showed peaks between 570 and $705 \mathrm{~cm}^{-1}$, i.e. at $472.56,551.64 \mathrm{~cm}^{-1}$ corresponding to S-S stretching of disulfide bond (Lo et al. 2012). In feather hydrolysate-containing chromium, these peaks were absent and a new peaks at 1608.63, 1521.84, 1506.41 , and $1029.99 \mathrm{~cm}^{-1}$ corresponding to $\mathrm{S}=\mathrm{O}$ bond present in cysteic acid were observed. This confirms that chromium reduction is taking place due to oxidation of cysteine to cystine and then to cysteic acid. The findings of this study are consistent with previous reports (Adari et al. 2008).

\section{Conclusion}

In this study, feather degradation by S. maltophilia KB13 has shown to be an efficient and ecofriendly approach to reduce the accumulation of feathers in the environment. The FPH obtained after degradation of chicken feather could be efficiently utilized for the reduction of chromium. The results of this study clearly demonstrate that sulfurcontaining amino acids such as cysteine and cysteine were solely responsible for the reduction process and that no bacterial enzyme was involved. This is the first report showing the potential use of FPH as an inexpensive source for chromium removal.
Fig. 4 FTIR spectrum of feather protein hydrolysate $($ red $)$ and $\mathrm{Cr}(\mathrm{VI})$ treated feather hydrolysate (green) presented the chemical groups involved in $\mathrm{Cr}(\mathrm{VI})$ reduction process
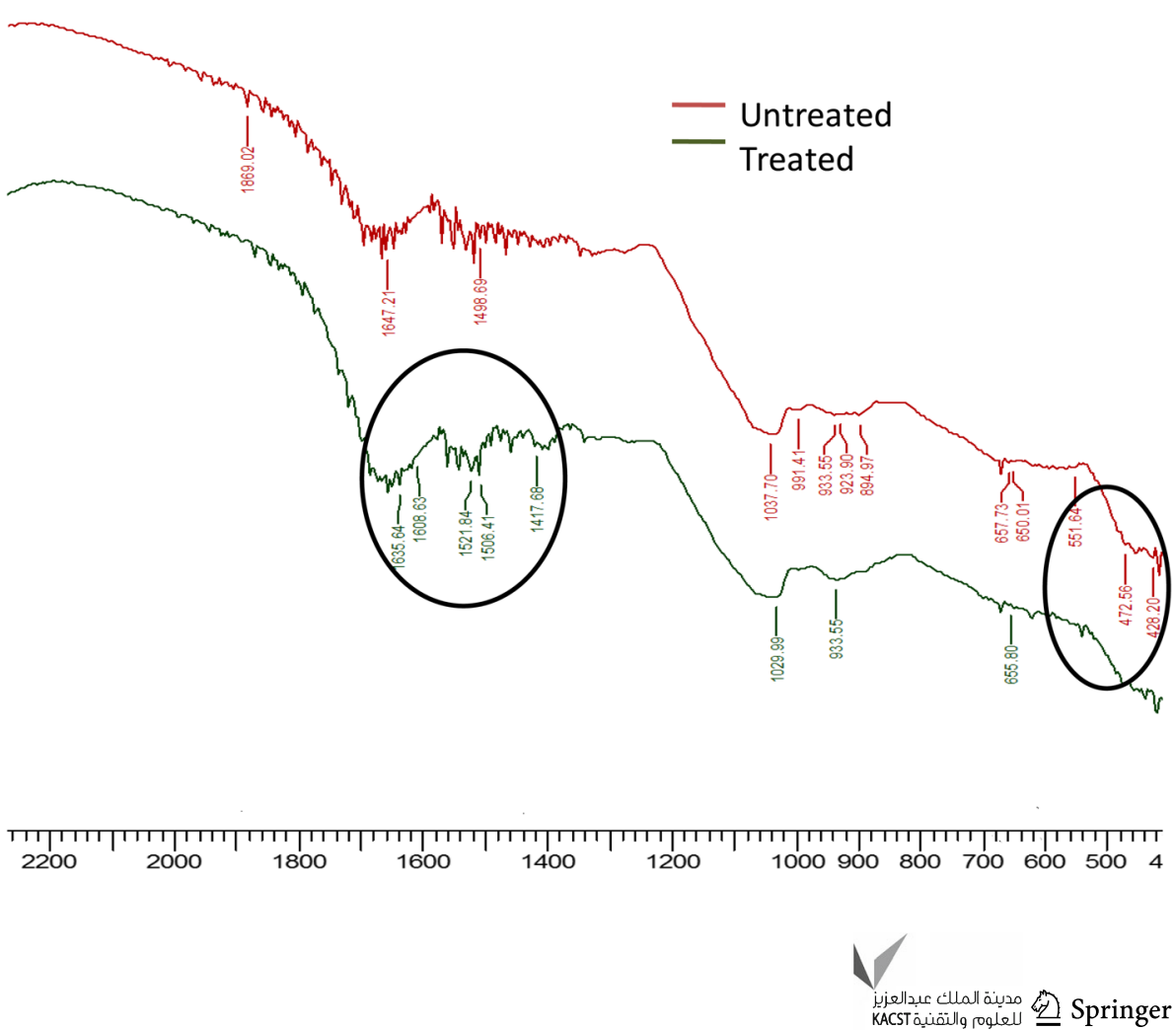
Acknowledgments This work was supported by Department of Biotechnology, Guru Ghasidas Vishwavidyalaya, India. The Chromous India Pvt. Ltd is thankfully acknowledged for the sequencing of bacterial strain.

\section{Compliance with ethical standards}

Conflict of interest The authors declare that they have no conflict of interest in the publication.

Open Access This article is distributed under the terms of the Creative Commons Attribution 4.0 International License (http:// creativecommons.org/licenses/by/4.0/), which permits unrestricted use, distribution, and reproduction in any medium, provided you give appropriate credit to the original author(s) and the source, provide a link to the Creative Commons license, and indicate if changes were made.

\section{References}

Adari KK, Nowduri A, Parvataneni V (2008) Oxidation of L-cys by chromium(VI) - a kinetic study. Bull Chem Soc 22:305-310

Alam MZ, Ahmad S (2012) Toxic chromate reduction by resistant and sensitive bacteria isolated from tannery effluent contaminated soil. Ann Microbiol 62:113-121

Alam MZ, Malik A (2008) Chromate resistance, transport and bioreduction by Exiguobacterium sp. ZM-2 isolated from agricultural soil irrigated with tannery effluent. J Basic Microbiol 48:416-420

Allegretti P, Furlong J, Donati E (2006) The role of higher polythionates in the reduction of chromium(VI) by Acidithiobacillus and Thiobacillus cultures. J Biotechnol 122:55-61

Anbu P, Gopinath SCB, Hilda A, Lakshmipriya T, Annadurai G (2007) Optimization of extracellular keratinase production by poultry farm isolates Scopulariopsis brevicaulis. Bioresour Technol 98:1298-1303

Ataabadi M, Hoodaji M, Tahmourespour A, Kalbasi M, Abdouss M (2015) Optimization of factors affecting hexavalent chromium removal from simulated electroplating wastewater by synthesized magnetite nanoparticles. Environ Monit Assess 187:4165

Bach E, Anna VS, Daroit DJ, Correa AP, Segalin J, Brandelli A (2012) Production, one-step purification, and characterization of keratinolytic protease from Serratia marcescens P3. Process Biochem 47:2455-2462

Bálint B, Bagi Z, Tóth A, Rákhely G, Perei K, Kovács K (2005) Utilization of keratin-containing biowaste to produce biohydrogen. Appl Microbiol Biotechnol 69:404-410

Bradford MM (1976) A rapid and sensitive method for the quantitation of microgram quantities of protein utilizing the principle of protein-dye binding. Anal Biochem 72:248-254

Chaturvedi V, Bhange K, Bhatt R, Verma P (2014) Production of keratinase using chicken feathers $\mathrm{s}$ substrate by a novel multifunctional strain of Pseudomonas stutzeri and its dehairing application. Biocatal Agric Biotechnol 3:167-174

Chen ZL, Megharaj M, Naidu R (2007) Speciation of chromium in waste water using ion chromatography inductively coupled plasma mass spectrometry. Talanta 72:394-400

Cheng X, Huang L, Tu X, Li K (2010) Medium optimization for the feather degradation by Streptomyces fradiae Var S-221 using the response surface methodology. Biodegradation 21:117-122

De Logu A, Uda P, Pellerano ML, Pouseda ML (2001) Comparison of two rapid calorimetric methods for determining resistance of
Mycobacterium tuberculosis to rifampin, isoniazid, streptomycin in liquid medium. Eur J Clin Microbiol 20:33-39

Deng S, Yu Q, Huang J, Yu G (2010) Removal of perfluorooctane sulfonate from wastewater by anion exchange resins: effects of resin properties and solution chemistry. Water Res 44:5188-5195

Eaton AD, Clesceri LS, Rice EW, Greenberg AE, Franson MAH (2005) Standard methods for the examination of water and wastewater: Centennial edition. American Public Health Association, Washington DC, p 1368

Ellman GL (1959) Tissue sulfhydryl groups. Arch Biochem Biophys 82:70-77

Fang Z, Zhang J, Liu B, Du G, Chen J (2013) Biodegradation of wool waste and keratinase production in scale-up fermenter with different strategies by Stenotrophomonas maltophilia BBE11-1. Bioresour Technol 140:286-291

Focardi S, Pepi M, Landi G, Gasperini S, Ruta M, Biasio PD, Focardi SE (2012) Hexavalent chromium reduction by whole cells and cell free extract of the moderate halophilic bacterial strain Halomonas sp. TA-04. Int Biodeterior Biodegrad 66:63-70

Fontoura R, Daroit DJ, Correa AP, Meira SM, Mosquera M, Brandelli A (2005) Production of feather hydrolysates with antioxidant, angiotensin-I converting enzyme and dipeptidyl peptidase-IVinhibitory activities. New Biotechnol 31:506-513

Holt JG, Krieg NR, Sneath PHA, Staley JT, Williams ST (1994) Bergey's manual of determinative bacteriology, 9th edn. Lippincott Williams and Wilkins, Philadelphia

Jeong JH, Lee OM, Jeon YD, Kim JD, Lee NR, Lee CY, Son HJ (2010) Production of keratinolytic enzyme by a newly isolated feather-degrading Stenotrophomonas maltophilia that produces plant growth-promoting activity. Process Biochem 45:1738-1745

Kwong DWJ, Pennington DE (1983) Stoichiometry, kinetics, and mechanisms of the chromium(V1) oxidation of L-cysteine at neutral pH. Inorg Chem 23:2532-2537

Lasekan A, Abu Bakar F, Hashim D (2013) Potential of chicken byproducts as sources of useful biological resources. Waste Manage 33:552-565

Lateef A, Oloke JK, Gueguim EB, Sobowale BO, Ajao SO, Bello BY (2010) Keratinolytic activities of a new feather-degrading isolate of Bacillus cereus LAU 08 isolated from Nigerian soil. Int Biodeterior Biodegrad 64:162-165

Lo W, Too J, Wu JY (2012) Production of keratinolytic enzyme by an indigenous feather-degrading strain Bacillus cereus $\mathrm{Wu} 2$. J Biosci Bioeng 114:1-8

Megharaj M, Avudainayagam S, Naidu R (2003) Toxicity of hexavalent chromium and its reduction by bacteria isolated from soil contaminated with tannery waste. Curr Microbiol 47:51-54

Quievryn G, Goulart M, Messer J, Zhitkovich A (2001) Reduction of $\mathrm{Cr}(\mathrm{VI})$ by cysteine: significance in human lymphocytes and formation of DNA damage in reactions with variable reduction rates. Mol Cell Biochem 222:107-118

Ren T, He P, Niu W, Wu Y, Ai L, Gou X (2013) Synthesis of $\alpha-\mathrm{Fe}_{2} \mathrm{O}_{3}$ nanofibers for applications in removal and recovery of $\mathrm{Cr}(\mathrm{VI})$ from wastewater. Environ Sci Pollut R 20:155-162

Riffel A, Brandelli A, Bellato CM, Souza GHMF, Eberlin MN, Tavares FCA (2007) Purification and characterization of a keratinolytic metalloprotease from Chryseobacterium sp. kr6. J Biotechnol 128:693-703

Santhana KKA, Kumar CU, Rajesh V, Rajesh N (2014) Microwave assisted preparation of $n$-butylacrylate grafted chitosan and its application for $\mathrm{Cr}(\mathrm{VI})$ adsorption. Int $\mathrm{J}$ Biol Macromol 66:135-143

Shrinivas D, Naik GR (2011) Characterization of alkaline thermostable keratinolytic protease from thermoalkylophilic Bacillus 
halodurans JB99 exhibiting dehairing activity. Int Biodeterior Biodegrad 65:29-35

Sultan S, Hasnain S (2007) Reduction of toxic hexavalent chromium by Ochrobacterium intermedium strain SDCr-5 stimulated by heavy metals. Bioresour Technol 98:340-344

Syed DG, Lee JC, Li WJ, Kim CJ, Agasar D (2009) Production characterization and application of keratinase from Streptomyces gulbargensis. Bioresour Technol 100:1868-1871

Taskin M (2013) A new strategy for improved glutathione production from Saccharomyces cerevisiae: use of cysteine- and glycinerich chicken feather protein hydrolysate as a new cheap substrate. J Sci Food Agric 93:535-541

Taskin M, Ozkan B, Atici O, Aydogan MN (2012) Utilization of chicken feather hydrolysate as a novel fermentation substrate for production of exopolysaccharide and mycelial biomass from edible mushroom Morchella esculenta. Int J Food Sci Nutr 63:597-602

Tatineni R, Doddapaneni KK, Potumarthi RC, Vellanki RN, Kandathil MT, Kolli N, Mangamoori LN (2008) Purification and characterization of an alkaline keratinase from Streptomyces Sp. Bioresour Technol 99:1596-1602
Thatoi H, Das S, Mishra J, Rath BP, Das N (2014) Bacterial chromate reductase, a potential enzyme for bioremediation of hexavalent chromium: a review. J Environ Manage 146:383-399

Tiwary E, Gupta R (2010) Medium optimization for a novel $58 \mathrm{kDa}$ dimeric keratinase from Bacillus licheniformis ER-15; Biochemical characterization and application in feather degradation and dehairing of hides. Bioresour Technol 101:6103-6110

Tsopmo A, Gao Q, Baakdah MM (2014) Reduction of hexavalent chromium by digested oat bran proteins. Food Chem 153:171-176

Wang WQ, Li MY, Zeng QX (2012) Thermodynamics of Cr(VI) adsorption on strong alkaline anion exchange fiber. Trans Nonferrous Metals Soc 22:2831-2839

Welch CM, Nekrassova O, Compton RG (2005) Reduction of hexavalent chromium at solid electrodes in acidic media: reaction mechanism and analytical applications. Talenta 65:74-80

Yamamura S, Morita Y, Hasan Q, Yokoyama K, Tamiya E (2002) Keratin degradation: a cooperative action of two enzymes from Stenotrophomonas sp. Biochem Biophys Res Commun 294:1138-1143 